\title{
The Growth of National Women's Tennis, 1904-1940
}

\author{
ANGELA LUMPKIN
}

When Mary Outerbridge brought the implements of the new British lawn sport of tennis to Staten Island in 1874, little did she realize that in just over a quarter of a century this sport would attract women enthusiasts from coast to coast. Prior to this national development, however, Victorian fashion and leisurely styles of play prevailed as predominately Eastern society women embraced the game. These Eastern players preferred a not-too-vigorous, though nonetheless competitive approach to tennis, hosting their first national championship in 1887. This domination by Easterners continued until 1899 when the first non-Easterner won the national championship. Then between 1904-1940, six California ladies (May Sutton, Mrs. Hazel Hotchkiss Wightman, Mary K. Browne, Mrs. Helen Wills Moody, Helen Jacobs, and Alice Marble) reigned atop the national tennis scene capturing twentythree national titles in singles. In addition to their championship performances, these six led in the

\section{About the Author}

Angela Lumpkin is an Assistant Professor of Physical Education at the University of North Carolina at Chapel Hill. perfecting of styles of play, affirming that the baseline game, the serve-and-volley game, as well as the all-court game were alternative approaches to victory. In these and other ways, this Californian sextet greatly enhanced the popularity and stature of tennis nationally.

Californians did not just start mass production of tennis players at the dawn of the twentieth century. While clubs were formed as early as the 1880 's, the ladies were reluctant to play the sport competitively until the late 1890's when numerous women vigorously adopted the game (Yates, 1890). Tennis in southern California was dominated in the early years of the twentieth century by the four Sutton sisters, Ethel, Violet, Florence, and May. Capturing between them eighteen Southern California Tennis Championships, frequently the quip emerged that it took a Sutton to beat a Sutton. A passionate and all-consuming devotion to tennis prodded the Suttons to construct their own court and to teach themselves how to play, even with balls minus covers and with borrowed racquets (Hoffman, 1953).

May Sutton emerged as the best of the quartet and following her domination of tennis throughout 
California, she travelled to Philadelphia for the national championships in 1904. Although reports of the higher standards of play in the East had reached the West coast, she did not find the competition too difficult and brought back with her the singles and doubles championships (Sutton, 1912).

May Sutton's vigorous game, including strong forehands, an overhead, mannish serve, and great footwork, first signaled a transition in the caliber and style of women's tennis (Potter, 1963). Sutton carried her winning style of play to England in 1905. By defeating England's best, Dorothea Douglas, in the singles finals, she became the first American mar. or woman champion at Wimbledon. Two years later she again captured the All-England title at Wimbledon giving her vigorous, though predominately baseline game three major singles championships.

During the 1902 Pacific Coast Championships a new disciple embraced tennis. Hazel Hotchkiss fell in love with the sport at her first sight of championship tennis, such as exhibited by Ethel and May Sutton and especially by the doubles play of Sam and Sumner Hardy. The Hardy brothers' precision in volleying and smashing, their split-second maneuvers which drew opponents out of position, and their quickness at the net kindled a desire in Hotchkiss to play similarly (Wind, 1972).

The graveled backyard of their home in Berkeley encouraged Hazel Hotchkiss and two of her brothers, Homer and Marius, to adopt the Hardy brothers' forte. Playing over a rope strung across the yard, dodging rosebrushes, and trying to hit the ball before it would er- ratically bounce from the gravel "court," Miss Hotchkiss learned the game that would start a revolution in women's tennis. Also, practicing solo against the wall of the Hotchkiss house, she learned to carefully control the ball to prevent a wild stroke from cracking one of the bay windows on either side of her "bandboard" (Wightman, personal interview, 1973).

Six months after taking up tennis, Hotchkiss entered her first tournament, the Bay Counties Women's Doubles Championship. She and her partner won without losing a set as Hotchkiss made history with the revolutionary tactics she employed.

Standing a yard and a half from the net when her partner served, she intercepted the majority of her opponents' returns and volleyed them for winners. She rushed forward to the net during rallies whenever a short return provided an opening, and stayed there instead of retreating to the backcourt. She followed in after her betters serves . . . to volley the return. These measures thoroughly demoralized her opponents, who had been brought up to think that woman's place was the baseline. The emancipation of woman from the backcourt was definitely under way. (Wind, 1952, p. 39)

From this somewhat spectacular beginning, she developed into an artist in doubles play, although in singles she was somewhat less formidable. A soft serve and less than overpowering drives left her little choice but to move to the net. When she played her volleying game against opponents who were not hard and accurate hitters, she was practically unbeatable.

In 1909 Hotchkiss travelled to Philadelphia and swept the singles, 
doubles, and mixed doubles crowns with her serve-and-volley game. She repeated this the next two years becoming the first person to win a triple-triple.

Following her marriage in 1912 to Bostonian George Wightman, she semi-retired from tennis for seven years to rear a family. During these years and those following she befriended numerous California players who came to play in the eastern tournaments, thereby helping bridge the gap between the East and the West. During her competitive career spanning twenty-nine years, she won a total of forty-five national titles, including four American singles championships. In addition to competing, Mrs. Wightman taught tennis to numerous potential stars and assisted with the development of others, such as fellow Californians Helen Wills and Helen Jacobs. This grand lady, born only twelve years after the first tennis ball was hit in this country reigned as the "Queen Mother" of national women's tennis for over half a century.

In 1912, 1913, and 1914 Mary K. Browne repeated Hotchkiss' tripletriple sweep in the national singles, doubles, and mixed doubles championships. Browne had learned her tennis on the fast, hard California courts at the hands of Tom Bundy and her brother, Nat Browne. Mary $\mathrm{K}$. Browne displayed a distinct net game which she combined with a brilliant, severe overhead game and with the ability to force openings with cunning changes of pace. With seemingly no weakness, she operated her game most effectively from just inside the service court line. From this position, she executed sharp overhead shots and low volleys at acute angles across the forecourt. She also moved eagerly to the net for volleying duels or anywhere on the court for smashes. Browne's game was based on sound principles of play and the court craft to plan her game. Hawthorne (1917) expressed it this way, "There is no woman in the world with a more comprehensive command of strokes and a fuller understanding of court technique" (p. 62).

This shift in tennis power from the East to the West drew many speculations about the transition. One contributor to the expertise these California racquet wielders displayed was the all-the-yearround practice made possible by the climate. More importantly, however, practice on hard surfaces with its resultant development of speed and accuracy aided performances. That is, accuracy of strokes while reacting to a faster pace of play provided the excellent laboratory setting in which to develop the game of the day, which stressed fast hitting, fast moving, and fast thinking. So, instead of the hesitation prompted by turf, asphalt demanded anticipation and quicker movement (Freeman, 1914).

Helen Wills entered the sporting scene of the 1920's when as a schoolgirl-looking prodigy with long, braided hair, she competed in her first national tournament in 1922. While losing in the finals, Wills gleaned a lesson that she reapplied throughout her long and brilliant career-" that simplicity of technique added to directness of attack are far more effective than fancy spins and exaggerated strokes" (Davidson \& Jones, 1971, p. 23). She did not favor the use of brute strength, but for her, power could be obtained through 
changes in the grip of the racket and at the same time be less demanding. She relied on anticipation, not speed of foot. A reverse or a slice adequately replaced any need for a kicking, overpowering serve as used by men. Even with hard-hitting baseline drives, her play was essentially feminine as women players at all levels of ability identified with her style of play (Metzler, 1970).

Wills' powerful game of groundstrokes with seldom any net play proved effective enough to bring her seven American singles titles and eight All-England singles crowns in fifteen years-a record unmatched by any other woman. She also captured four French titles. Combined, this made Helen Wills the "Queen" of women's tennis from 1926-1938.

Contemporary with Helen Wills, and ironically from the same home town, was the "Other Helen." Helen Jacobs, two years junior to Helen Wills, followed in the footsteps, and often the shadow, of the older champion. In her own right, though, Jacobs did develop into a champion with the assistance of some good teachers.

Those who did the most for me during the formative years of my tennis career were William C. "Pop" Fuller, of the Berkeley Tennis Club. Mr. Fuller was a retired druggist with a great love and knowledge of the game. He also coached Helen Wills and other young players of the time. Mrs. Hazel Wightman, on visits to her home town, Berkeley, was very helpful to me, as was Bill Tilden, over the years. Mrs. Wightman and I have always been friends, and she did much to instil (sic) in me the importance of calm concentration on the court. . . . (personal correspondence)
Helen Jacobs played an "allcourt" game of tennis combining backcourt drives with volleys and overheads at the net. She lacked some power and top spin on her drives, yet substituted sliced forehands and backhands which became devastating weapons against most of her opponents. Jacobs to date has remained the only woman champion to win the American singles title four consecutive years (1932-1935).

Mrs. Hazel Wightman after "discovering" and instructing both Wills and Jacobs, recommended that they play each other to promote tennis in California. This set the stage for their first match, which the older Wills won easily. Because of the age and experience differences favoring Wills and making the matches one-sided, the exhibitions did not work out, but these two champions continued to oppose each other occasionally in tournament finals. The press at the time, and historians since then, have misrepresented their relationship as a feud. Mrs. Wightman, who knew both well, emphasized the differences in their personalities, their ambitions, and their overall attitudes as the reasons that they were not close friends. But, she affirmed, they were not enemies (Wightman, personal interview, 1973). Jacobs agreed that their relationship was merely "an intense competitive tennis situation" (personal correspondence).

In Jacobs' only defeat of Mrs. Helen Wills Moody in a national singles championship in 1933, the older champion defaulted in the third set due to a back injury. The aftermath, although distorted by many, showed no harsh attitudes, nor reactions, between the two 
champions. Two years later on the center court at Wimbledon the rematch of the century pitted the two Helens against one another. Victorious, Mrs. Moody achieved vindication from the repercussions of the 1933 default and forced Jacobs to have to wait until 1936 for her Wimbledon singles crown.

The two Helens bequeathed their champion-status to San Francisco's Alice Marble who became America's singles title holder in 1936. Encouraged by her brother Dan, Marble eagerly pursued tennis, mostly on her own without formal lessons. Even after she began tournament competition, she still lacked knowledge of the basics of strokes and strategy. At her first national tournament, Marble was advised by fellow Californian and former champion, Mary $\mathrm{K}$. Browne, to secure a coach to teach her these basics. Taking Browne's advice, she secured two coaches, Harwood White who changed her grip and taught her the basics of the strokes and Eleanor Tennant who helped perfect these and who became her career coach (Marble, 1946).

Marble was the first woman to play the so-called "big game," adopting from men stars such as Maurice McLaughlin and Ellsworth Vines the big serve-and-power game. With a kicking action and a mighty swing, she exhibited the first power serve used consistently and successfully by a woman. Following this attacking serve, she moved to the net to intercept any returns with vicious overheads and well-placed volleys.

Her first hard-kicking Americantwist serve and the finality of her smashes give her an advantage never before enjoyed by any other woman player in the history of the sport, for she stands supreme in overhead play among the immortals of the game. (Nason, et al., 1940, p. 309)

Two limitations prevented Marble from attaining the heights predicted by conjecturers during her early years in national tournaments. First, she experienced a health problem. A bout with sunstroke and anemia in a 1933 tournament when she played 11 sets and 108 games in one day followed by a disease diagnosed as tuberculosis appeared to terminate her career. Marble's determination and courage, however, combined to replace an invalid life with four national singles titles within five years. Secondly, Marble traded in her amateur status in 1940 for a professional tour as Mary $K$. Browne had done in 1926. Marble described her decision to accept the tour as follows: "I turned professional to pay back a number of obligations and because tennis was over in Europe due to the war" (personal correspondence). Thus, the annals of tennis will never record the heights to which Marble might have attained if she had been healthy and if she had continued to have international tournament opportunities as an amateur.

Two summarizing observations concerning the six California champions who led women's tennis during the first forty years of the twentieth century have been made by this writer. During the thirtyseven years between May Sutton's only national singles title in $\mathbf{1 9 0 4}$ and Alice Marble's last singles crown in 1940, this sextet won the American championship twentythree times. They also won twelve 
Wimbledon crowns. Secondly, a parallel has been drawn between their styles of play, with two people representing each of the three general "games." May Sutton and Mrs. Helen Wills Moody predominately played a driving, baseline game. Mrs. Hazel Hotchkiss Wightman and Alice Marble based their game on advancing to the net for volleys, although Marble added the power serve. Mary K. Browne and Helen Jacobs combined groundstrokes with volleys and overheads to exhibit more of an all-court game. These observations, hopefully, have reemphasized the leadership in style and caliber of play displayed by those West Coast champions.

In addition to vying for numerous national championships, these six winners influenced other facets of the sport. May Sutton with her shorter skirts, fewer petticoats, avoidance of high-collared shirtwaists, and rolled up sleeves, pioneered women's emancipation from medieval sports attire (Cummings, 1957). Mrs. Helen Wills Moody popularized the use of a white eyeshade. Both Helen Jacobs and Alice Marble favored shorts rather than dresses for play.

Competition for college-age women, non-existent prior to the 1930 's, was initiated by Mrs. Hazel Wightman through invitational collegiate tournaments in Boston (personal correspondence). Mary $\mathrm{K}$. Browne expanded this idea opening the tournaments she co-sponsored with Ohio's Lake Erie College to college women, plus others who could add to the caliber of play. The first of the Mary K. Browne Invitational Tournaments took place on the courts of Lake Erie College on June 14, 15, 16, 1934
(Painesville Telegraph, June 15, 1934, p. 12).

Only once in history have American women vied for gold in Olympic tennis competition. In the 1924 games in Paris, France, Mrs. Hazel Wightman captured two gold medals in women's doubles and in mixed doubles, while Helen Wills captured the singles gold medal and teamed with Wightman for the doubles win-a complete sweep of the gold medals by the American women (Schaap, 1963).

Lastly, as a combined contribution to tennis both on and off the court, Mrs. Hazel Wightman conceived the idea of an international competition. Once the concept crystallized, she recommended an international team match to the president of the United States Lawn Tennis Association in 1920 and even purchased and donated a cup for the event. Forgotten until the stadium at Forest Hills, New York, needed a distinguished opening event in 1923, suddenly, the "Wightman Cup" matches became a reality. First pitting America's and England's finest women players, the challenge matches continued to include only these two nations. Led by Wightman, Browne, Wills, Jacobs, and Marble the United States captured the Wightman Cup thirteen times between 1923-1940.

Dominate, indeed they did! These six Californians contributed the new and perfected styles of play which captured championships during the early twentieth century. They influenced clothing styles and expanded competitive opportunities both nationally and internationally. Without them, tennis as known in the 1970's might indeed have advanced toward its present popularity much slower. 
At least, these women played a viable part in the development of tennis into a truly national sport and pastime.

\section{REFERENCES}

Cummings, P., American tennis, Boston: Little, Brown and Company, 1957.

Davidson, O. and Jones, C. M., Great women tennis players, London: Pelham Books, 1971.

Freeman, L. R., Why California tennis players win, Outing, LXV, October, 1914.

Hawthorne, F., Following the ball, Outing, LXXI, October, 1917.

Hoffman, J., The Sutton sisters, The racquet, XLVIII, August, 1953.

Marble, A., The road to Wimbledon, New York: Charles Scribner's Sons, 1946.

Metzler, P., Tennis styles and stylists, New York: The Macmillan Company, 1970.

Nason, J. et. al., Famous athletes of today, Boston: L. C. Page and Company, 1940.
Painesville (Ohio) Telegraph, June 15, 1934, p. 12.

Personal correspondence between Helen Hull Jacobs and the writer.

Personal correspondence between Alice Marble and the writer.

Personal correspondence between Mrs. Hazel Hotchkiss Wightman and the writer.

Potter, E. C., Jr., Kings of the court, New York: Charles Scribner's Sons, 1963.

Schaap, R., An illustrated history of the Olympics, New York: Alfred A. Knopf, 1963.

Sutton, M. G., My career as a lawn tennis player, American lawn tennis, VI, May 15, 1912.

Wind, H. W., Profiles: Run Helen!, The New Yorker, XXVIII, August 30, 1952, p. 39.

Wind, H. W., The story of Hazel Hotchkiss Wightman, The fireside book of tennis, eds. Allison Danzig and Peter Schwed, New York: Simon and Schuster, Inc., 1972.

Wightman, H. H., personal interview, December 7, 1973.

Yates, C. R., Lawn tennis on the Pacific Coast, Outing, XVI, July, 1890. 
Copyright of Quest (Human Kinetics) is the property of Human Kinetics Publishers, Inc. and its content may not be copied or emailed to multiple sites or posted to a listserv without the copyright holder's express written permission. However, users may print, download, or email articles for individual use. 